Review article

\title{
Coping strategies in midwife care for women with labour pain
}

\author{
Eva Šalanská ${ }^{1 *}$, Markéta Moravcová ${ }^{2}$ \\ ${ }^{1}$ Jan Evangelista Purkyně University, Faculty of Health Studies, Department of Nursing and Midwifery, Ústí nad Labem, Czech Republic \\ ${ }^{2}$ University of Pardubice, Faculty of Health Studies, Department of Midwifery and Health and Social Work, Pardubice, the Czech Republic
}

\begin{abstract}
Objective: Literary review; analysis of literary sources dealing with midwives who use coping strategies in care of women with labour pain. Design: A review study.

Methodology: Qualitative study; system search in the electronic databases Pubmed, Web of Science, midwives magazine, CINAHL, Cochrane, according to established criteria and the following keywords: coping, birth, labour pain, strategy. The overview was made within the period between September 2017 and June 2018. Selected studies were reviewed from the years 2000-2014. The obtained studies were organized according to Prism recommendations.

Results: A comparison of studies from the UK, Ireland, America and Australia. The study showed the positive impact of a midwife who uses a coping strategy while engaging a woman in the labour process and allowing her to decide on its course. This relationship leads to a better understanding and perception of birth pain by women as something positive and needed in childbirth; it is co-operation with a midwife and managing the birth itself without risks and complications.

Conclusions: The idea of modern nursing in midwifery is comprehensive, ongoing care for a woman by midwives during pregnancy, childbirth and the postpartum period taken as a relationship and supported by a woman's trust. This leads to the elimination of the disruption of natural processes of labour and delivery, the reduction of possible risks and complications, and to a positive pregnancy, childbirth and following contact between women and their newborns.
\end{abstract}

Keywords: Care; Coping; Delivery; Obstetrics; Strategy

\section{Introduction}

Birth pain is a specific obstetric phenomenon that differs from classical pain and it is usually described as the worst experience in a woman's life, but her perception and experience of this can be very individual. Birth pain is affected by many factors, so it is very difficult to judge the nature of this phenomenon (Mander, 2014).

Roberts et al. (2010) considers the aim of evaluating pain to ensure maximum well-being and the self-sufficiency of the individual. It is a complex physiological matter to understand birth pain and the psychological aspects of its origin, pain management, its diagnosis, evaluation, determination of intensity and pain relieving (both pharmacologically and non-pharmacologically).

Mander (2014) states that the management of birth pain includes (besides the reported psychoprophylaxis to childbirth), the correct method of prenatal preparation, the presence of a person who is close to the mother during childbirth; the importance of the role of the midwife during childbirth and care of a woman. Birth pain is a special category of pain, combining physiological significance with pathophysiological mechanisms. This is an acute pain that combines various pathophysiological mechanisms of women (visceral, nonseptic and neuropathic). The source of birth pain is the stretching of soft tissues during labour, the pressure of the fetal head in labour, and hormonal influence. Birth pain is intended to help women look for various relief positions that help fetal descent and accelerate childbirth, which, on the contrary, is perceived as positive in the course of childbirth. Women know that birth pain is a physiological issue and it is not a sign of danger of any organ damage. The positive influence of birth pain is the establishment of a strong contact between a mother and a child, the change of woman's self-esteem, the change of her role in life (Raudenská et al., 2014). For this reason, many questions are raised in relation to whether it is a painful process or not. Therefore, it is good to focus on birth pain in a comprehensive way, to help women to work with birth pain and better manage childbirth. Several studies have shown that informed women who have accepted birth defects can experience labour pain, birth and maternity in a positive. In childbirth, when labour pain is pharmacologically regulated, endorphins are not naturally produced; they are washed out throughout delivery

\footnotetext{
* Author for correspondence: Eva Šalanská, Jan Evangelista Purkyně University, Faculty of Health Studies, Department of Nursing and Midwifery, Velká Hradební 13, 40001 Ústí nad Labem, Czech Republic; e-mail: eva.salanska@ujep.cz http://doi.org/10.32725/kont.2019.018
}

Submitted: 2019-01-02 • Accepted: 2019-04-08 • Prepublished online: 2019-06-19 
and after delivery in the body, resulting in a feeling of mutual affection between a mother and a fetus and then create a sense of well-being and help a woman overcome childbirth. For this reason, it is desirable to focus on helping women to cope with birth pain in a non-pharmacological way using coping strategies. The choice of method of relief from birth pain should be based on the preference of a particular woman (Ratislavová, 2008, p. 12).

The consequences of non-controlling of birth pain can be uterine cervical damage after delivery, pelvic muscularity, fetal stress, and negative birth experiences that can induce longterm mental trauma in women. On the contrary, the support from a midwife and the application of a suitable coping strategy can better help women with birth pain and coping with the birth process itself (Raudenská et al., 2014).

Target: The aim was to find and analyse studies on birth pain, perception, childbirth and birth pain management by women, and the care delivered by midwives.

Methodology: A literary review was completed. Selection Criteria: qualitative research method was chosen for the analysis, as well as a quantitative study dealing with labour pain and coping strategies.

The selection criteria for the literary review are as follows: English full texts, reviewed articles, or expert studies. The specified time span for the article search is from 1990 until 2015. The selected studies are from 2000 until 2014.

Resources: The bibliographic databases CINAHL, Medline, PubMed and Web of Science were used to obtain relevant resources. The search for relevant articles ran from September 2017 until June 2018, and later they were processed.

Search: The search strategy was based on pre-defined search terms: coping, care, birth pain, birth, strategy. We used the "OR" and "AND" Boolean operators, and the keyword boundaries "labour pain in coping strategy" to ensure that this particular phrase was searched. Initial searches exclud- ed articles that did not contain keywords, articles published in a language other than English, or books or book reviews. The content analysis was performed on the publications containing all these keywords. Articles that did not meet these criteria were removed, as well as the abstracts, articles of non-reviewed journals and documents (systematic reviews, book reviews, articles) that did not concern themselves with clarifying the concept. We used gradual decommissioning according to the PRISMA recommendation (Diagram 1). Out of a total of 32 searches, 10 articles met the criterion. Articles that describe quantitative studies were phased out.

Selection and analysis of studies: After further verification of the article, only qualitative studies were selected for the final analysis. Relevant studies were critically read, analysed and described in detail. The methodological quality of the studies was not assessed.

The data found has been included in the report. The purpose of this work is to improve the understanding of birth pain, women's management of labour pain, and the help of midwives in a non-pharmacological way by using coping strategies. Further work can be done in EBM evidence-based midwifery for designing an effective midwife care plan for a woman during both physiological and risky births. It can also help with the evaluation of labour pain and the possibility of using different coping strategies to help women with birth pain and the creation of nursing documentation in the midwife's room for midwives who are assisting with labour pain.

\section{Results}

10 studies from the UK, Ireland, Iran, America and Iceland were compared: eight studies used a phenomenological review of the remaining two without a specific qualitative methodological perspective. Analysis was used to synthesize the data in

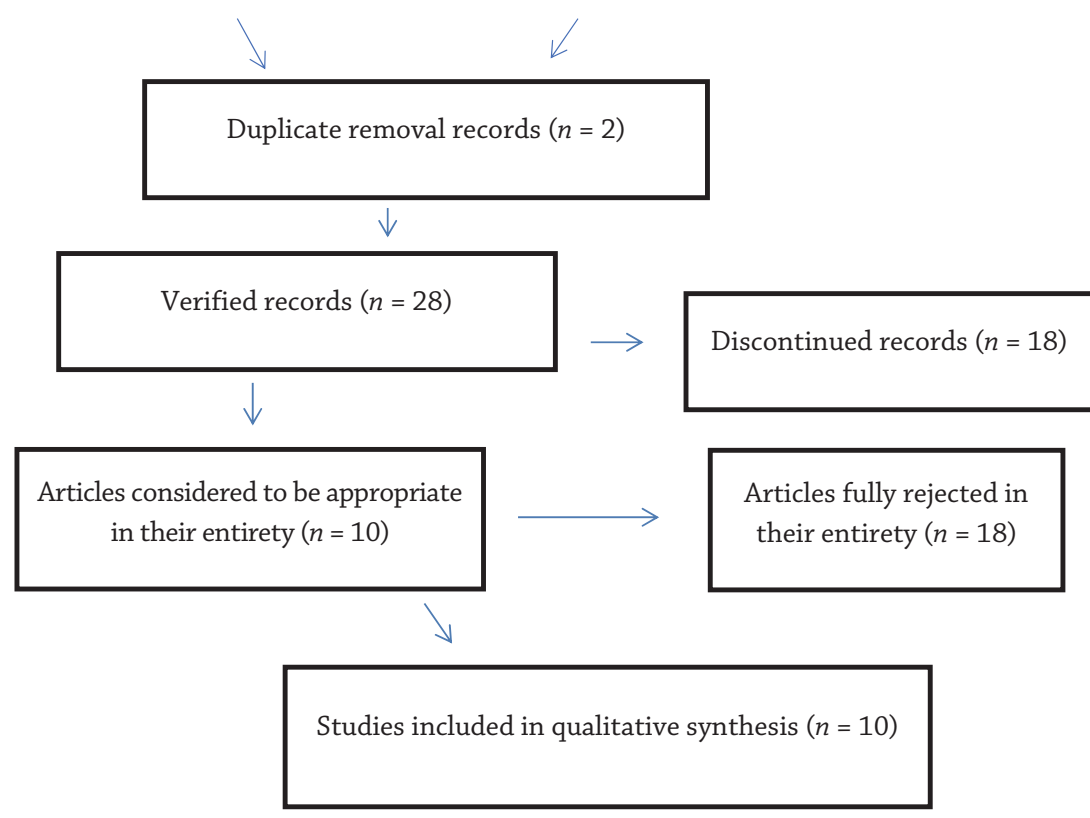

Diagram 1. Selection and Classification of Studies - PRISMA 
this report. The studies of Escott et al. (2004), Gibson (2014), Lundgren and Dahlberg (2002), Karlsdottir et al. (2014), Leap et al. (2010), Rachmawati (2012), Roberts et al. (2010), Slade et al. (2000) and Whitburn et al. (2014) indicate that women perceive birth pain as something positive mainly because of the help and support from a midwife using coping non-pharmacological strategies to help them better manage childbirth. Feeding pain is measured as tolerable when compared to women who used pain relief during the delivery supported with pharmacological methods. All the results (Table 1.) pointed out the positive impact of a midwife who behaved empathically, tried to involve the woman in the birth process, and allowed the woman to decide on the process and used a coping strategy to provide care. This model of midwifery care leads to a decrease in the use of pharmaceuticals and complications during birth, such as birth induction, episiotomy, VEX, and birth of SC (Klomp et al., 2013; Kuliukas et al., 2016).

Table 1. Overview of the studies related to midwife care with a coping strategy application

\begin{tabular}{|c|c|c|c|}
\hline $\begin{array}{l}\text { Author/year/ } \\
\text { country }\end{array}$ & $\begin{array}{l}\text { Hypotheses/ } \\
\text { objectives }\end{array}$ & $\begin{array}{l}\text { Types of research/methodology/ } \\
\text { Type of respondents }\end{array}$ & Results/findings \\
\hline $\begin{array}{l}\text { Lundgren and } \\
\text { Dahlberg (2002); } \\
\text { Sweden }\end{array}$ & $\begin{array}{l}\text { Describe the } \\
\text { experience of women } \\
\text { with birth pain } \\
\text { during childbirth. }\end{array}$ & $\begin{array}{l}\text { A qualitative study using a phenomenological approach. } \\
\text { The method in the form of semi-structured interviews - } \\
\text { interviews, recorded on audio recording. Nine experienced } \\
\text { midwives with between } 12 \text { and } 28 \text { years of midwifery } \\
\text { practice rated nine women after delivery. Women } \\
\text { who were evaluated: four women delivering their first } \\
\text { born; three women delivering their second born; two } \\
\text { women from the third generation; women aged } 23 \text { to } \\
\text { 31; four women were college educated; women without } \\
\text { pharmacological methods to reduce birth defects. }\end{array}$ & $\begin{array}{l}\text { A positive approach to midwives assisting } \\
\text { during delivery is available, Communication } \\
\text { and relationship between a woman and a } \\
\text { midwife, support of women's self-confidence. } \\
\text { Partner at childbirth. }\end{array}$ \\
\hline $\begin{array}{l}\text { Escott et al. } \\
\text { (2004); } \\
\text { England }\end{array}$ & $\begin{array}{l}\text { Find out whether } \\
\text { women can identify } \\
\text { their own existing } \\
\text { strategies for } \\
\text { managing pain } \\
\text { and anxiety during } \\
\text { delivery, and whether } \\
\text { they can describe the } \\
\text { extent of mastering } \\
\text { strategies. }\end{array}$ & $\begin{array}{l}\text { Qualitative studies, semi-structured interviews. The } \\
\text { interviews were conducted in two nursery centres in } \\
\text { the north of England, lasting for } 40 \text { to } 50 \text { minutes. } \\
\text { Respondents were women giving birth for the first time. } \\
23 \text { women were interviewed in the third trimester, aged } \\
17-38 \text {, about what techniques to reduce anxiety were used } \\
\text { most often. Women were most likely to have tried to use } \\
\text { various relaxation techniques. Eventually, women were } \\
\text { asked after delivery. This sample consisted of } 20 \text { women } \\
\text { who did not attend any pre/post courses. In the first } \\
72 \text { hours, an interview was conducted with women who } \\
\text { were having their first experience of childbirth and labour } \\
\text { pain. Women were asked what strategies they used in } \\
\text { labour to manage birth pain and the anxiety associated } \\
\text { with it. Women reported the most: the use of coping } \\
\text { techniques such as breathing, relief, and hydrotherapy } \\
\text { offered by midwives. Parents rated positively the care of } \\
\text { the midwife and the choice of coping techniques they had } \\
\text { chosen themselves. }\end{array}$ & $\begin{array}{l}\text { They were divided into the following areas: } \\
\text { alignment with past experience of pain, } \\
\text { anxiety during the labour process. } \\
\text { Four major concepts that were identified } \\
\text { in an interview with all the women were } \\
\text { important: labour pain, related factors of } \\
\text { pain in labour, results of pain in labour, } \\
\text { perception of candidates with regards to the } \\
\text { help of the midwife. } \\
\text { All of the women again reported a positive } \\
\text { approach of the midwife. The women were } \\
\text { grateful for the choice of strategic methods } \\
\text { to help with birth pain, noticing the } \\
\text { importance of empathy, communication and } \\
\text { positive attitudes of a midwife }\end{array}$ \\
\hline $\begin{array}{l}\text { Roberts et al. } \\
\text { (2010); } \\
\text { America }\end{array}$ & $\begin{array}{l}\text { Evaluate the use } \\
\text { of alternative } \\
\text { techniques to assess } \\
\text { birth defects during } \\
\text { childbirth and help } \\
\text { women adapt to birth } \\
\text { pain. }\end{array}$ & $\begin{array}{l}\text { Qualitative studies. At the American College of Nurses, } \\
\text { they conducted semi-structured interviews with } \\
\text { nurses and birth attendants. The study looked at the } \\
\text { assessment of birth pain and the use of pharmacological } \\
\text { and non-pharmacological techniques to reduce birth } \\
\text { pain in nursing practice. The evaluated group of nurses } \\
\text { and midwives evaluated the use of pharmacological and } \\
\text { alternative non-pharmacological techniques to combat } \\
\text { labour pain. }\end{array}$ & $\begin{array}{l}\text { Using alternative techniques to help with } \\
\text { birth pain - a positive perception of women, } \\
\text { which has led to the elimination of birth } \\
\text { pain during childbirth. } \\
\text { Nurses and midwives rated this model as } \\
\text { effective because it better helped women } \\
\text { in the psychological field to reduce stress } \\
\text { during childbirth, improved women's } \\
\text { self-esteem, improved birth adaptation } \\
\text { and labour pain using coping strategies, } \\
\text { which reduced the use of pharmacological } \\
\text { techniques to suppress birth pain and } \\
\text { reduced various complications during } \\
\text { childbirth. }\end{array}$ \\
\hline $\begin{array}{l}\text { Slade et al. } \\
\text { (2000); } \\
\text { Great Britain }\end{array}$ & $\begin{array}{l}\text { Assess whether native } \\
\text { women actually use } \\
\text { coping strategies } \\
\text { to help ease birth } \\
\text { defects during } \\
\text { childbirth with } \\
\text { benefits. }\end{array}$ & $\begin{array}{l}\text { Qualitative studies, semi-structured interviews that were } \\
\text { conducted in women experiencing labour for the first time } \\
\text { in selected birth centres in the UK. The study included } \\
\text { women giving birth for the first time. The women were } \\
\text { of English nationality, aged } 18-44 \text {. The women were } \\
\text { monitored for } 11 \text { months. } \\
\text { The study involved } 121 \text { women. }\end{array}$ & $\begin{array}{l}\text { Positive perception of alternative techniques } \\
\text { to help with } \\
\text { birth pain. They were effectively used } \\
\text { in breathing strategies, but with lower } \\
\text { efficiency in relaxation and posture. } \\
\text { The proportion of breathing and relaxation } \\
\text { showed a weak association with lower fear. } \\
\text { The work discusses the modification of the } \\
\text { prenatal preparation to facilitate the use of } \\
\text { strategies. }\end{array}$ \\
\hline
\end{tabular}




\begin{tabular}{|c|c|c|c|}
\hline $\begin{array}{l}\text { Author/year/ } \\
\text { country }\end{array}$ & $\begin{array}{l}\text { Hypotheses/ } \\
\text { objectives }\end{array}$ & $\begin{array}{l}\text { Types of research/methodology/ } \\
\text { Type of respondents }\end{array}$ & Results/findings \\
\hline $\begin{array}{l}\text { Gibson (2014); } \\
\text { America }\end{array}$ & $\begin{array}{l}\text { Positive perception } \\
\text { of alternative } \\
\text { techniques to help } \\
\text { with birth pain. } \\
\text { They were effectively } \\
\text { used in breathing } \\
\text { strategies, but with } \\
\text { lower efficiency } \\
\text { in relaxation and } \\
\text { posture. } \\
\text { The proportion } \\
\text { of breathing and } \\
\text { relaxation has shown } \\
\text { a weak association } \\
\text { with lower fear. The } \\
\text { work discusses the } \\
\text { modification of the } \\
\text { prenatal preparation } \\
\text { to facilitate the use of } \\
\text { strategies. }\end{array}$ & $\begin{array}{l}\text { Qualitative research, method of semi-structured } \\
\text { interviews. The interviews were conducted at the } \\
\text { University of South Carolina at the Department of } \\
\text { Anthropology. Comparison of birth and labour births by } \\
\text { women, with } 40 \text { women giving birth under the guidance } \\
\text { of an obstetrician and } 40 \text { women under the guidance of a } \\
\text { midwife. } \\
\text { The interviews were conducted in women before and } \\
\text { afterwards in the postpartum period. In total, } 80 \text { women } \\
\text { participated in the survey. The interview was conducted } \\
\text { for } 30-60 \text { minutes. A total of } 80 \text { women participated in } \\
\text { the research, of which } 40 \text { were giving birth under the } \\
\text { guidance of an experienced obstetrician and } 40 \text { under the } \\
\text { guidance of a midwife. The study included women giving } \\
\text { birth for the first time, but also women more experienced } \\
\text { with labour. }\end{array}$ & $\begin{array}{l}\text { The women in both groups dealt with pain in } \\
\text { preterm delivery after pre-natal courses and } \\
\text { post-partum delivery. } \\
\text { Women who chose midwives to give birth } \\
\text { indicated that they were more familiar with } \\
\text { birth pain and that they were offered more } \\
\text { help with pain through various methods of } \\
\text { non-physical treatment. While women who } \\
\text { chose doctors confirmed that pain relief } \\
\text { was more helpful using pharmaceutical } \\
\text { methods. It follows that the same number } \\
\text { of women expressed concerns about } \\
\text { pain during childbirth during prenatal } \\
\text { interviews. While more women who talked } \\
\text { about a more painful birth had a negative } \\
\text { experience, they were disappointed that } \\
\text { they had been offered only pharmacological } \\
\text { pain relief methods. The trend is bringing } \\
\text { a higher demand for alternative pain relief } \\
\text { techniques. }\end{array}$ \\
\hline $\begin{array}{l}\text { Beige et al. } \\
\text { (2010); } \\
\text { Iran }\end{array}$ & $\begin{array}{l}\text { Evaluate the } \\
\text { experience of women, } \\
\text { evaluate the factors } \\
\text { that affect the } \\
\text { experience of labor } \\
\text { pain. }\end{array}$ & $\begin{array}{l}\text { Qualitative phenomenological study. In total, } 14 \text { women } \\
\text { undergoing semi-structured interviews/review, took part } \\
\text { in the study within } 6 \text { weeks. Women were included in the } \\
\text { study after they had had a natural birth. Nine women gave } \\
\text { birth for the first time, four women experienced birth } \\
\text { giving for the second time, and one woman had already } \\
\text { given five births. The women were aged 18-35. Data was } \\
\text { analysed using a seven-step method (Colaizzi). }\end{array}$ & $\begin{array}{l}\text { The women in both groups dealt with pain } \\
\text { in childbirth, pre-natal, postpartum and } \\
\text { postpartum. The women who chose to give } \\
\text { birth with the aid of a midwife stated that } \\
\text { they were more familiar with the birth } \\
\text { pain. They were offered more help with pain } \\
\text { through various methods of non-physical } \\
\text { treatment. } \\
\text { While the women who opted for a doctor } \\
\text { confirmed that they were more helped by } \\
\text { pain using pharmaceutical methods. It } \\
\text { follows that the same number of women } \\
\text { expressed concerns about pain during } \\
\text { childbirth in the prenatal interviews. } \\
\text { While more women who chose to give } \\
\text { birth with the help of a doctor, talked } \\
\text { about a more painful birth. Women had a } \\
\text { negative experience, they were disappointed } \\
\text { that they were offered the choice of only } \\
\text { pharmacological pain relief methods. } \\
\text { Nowadays, many women face the problem } \\
\text { that non-pharmacological pain relief } \\
\text { methods are seldom used in medically } \\
\text { attended births, which, of course, leads to } \\
\text { further problems, such as birth defects, } \\
\text { etc. The trend shows a higher demand for } \\
\text { alternative pain relief techniques. }\end{array}$ \\
\hline $\begin{array}{l}\text { Leap et al. } \\
(2010) ; \\
\text { Great Britain }\end{array}$ & $\begin{array}{l}\text { Evaluation of the } \\
\text { use of continuous } \\
\text { care of the midwife, } \\
\text { depending on the use } \\
\text { of pharmacological } \\
\text { methods to reduce } \\
\text { birth pain. A partial } \\
\text { goal was to evaluate } \\
\text { the use of coping } \\
\text { strategies in women } \\
\text { during childbirth } \\
\text { depending on labor } \\
\text { pain. }\end{array}$ & $\begin{array}{l}\text { A thematic analysis, a qualitative survey was carried out } \\
\text { using the semi-structured interview method - audiopedic } \\
\text { depth review. Interviews were conducted in women within } \\
2 \text { hours after the birth in the birth hall. } \\
\text { The interviews were recorded using audio recording. } \\
\text { The survey included } 10 \text { women. Respondents were aged } \\
\text { 18-40. Women evaluated the care of the midwife in the } \\
\text { form of continuous care, depending on the management } \\
\text { of labour pain and the use of pharmacological and non- } \\
\text { pharmacological methods. }\end{array}$ & $\begin{array}{l}\text { The results of the interviews confirmed that } \\
\text { in this form of care, women were better able } \\
\text { to manage birth pain and significantly less } \\
\text { enjoyed pharmacological methods of pain } \\
\text { relief compared to non-pharmacological } \\
\text { methods. Women rated positively birth } \\
\text { control, labour pain, and were more satisfied } \\
\text { with the care of the midwife who provided } \\
\text { them with individual continuous care. } \\
\text { Women reported that there was greater } \\
\text { trust between them and midwives, which } \\
\text { improved their overall relationship. } \\
\text { These experiences have increased women's } \\
\text { ability to overcome fear and self-doubt about } \\
\text { how they cope with pain and lead to a sense } \\
\text { of pride, enthusiasm and empowerment in } \\
\text { postnatal life. Women seemed to be more } \\
\text { encouraged and supported during childbirth, } \\
\text { more cooperative with a midwife, and to use } \\
\text { various non-pharmacological methods to } \\
\text { manage labour pain, positioning, breathing } \\
\text { training, hydrotherapy and more. All women } \\
\text { managed to give birth without the use of } \\
\text { pain-relieving pharmacological methods. }\end{array}$ \\
\hline
\end{tabular}




\begin{tabular}{|c|c|c|c|}
\hline $\begin{array}{l}\text { Author/year/ } \\
\text { country }\end{array}$ & $\begin{array}{l}\text { Hypotheses/ } \\
\text { objectives }\end{array}$ & $\begin{array}{l}\text { Types of research/methodology/ } \\
\text { Type of respondents }\end{array}$ & Results/findings \\
\hline $\begin{array}{l}\text { Rachmawati } \\
\text { (2012); } \\
\text { Indonesia }\end{array}$ & $\begin{array}{l}\text { Describe the } \\
\text { experience of women } \\
\text { with birth control } \\
\text { and evaluate the } \\
\text { factors that affect the } \\
\text { experience of birth } \\
\text { pain and the care } \\
\text { associated with it. }\end{array}$ & $\begin{array}{l}\text { Qualitative study, interpretative notes. Semi-structured } \\
\text { interviews were conducted - interviews with } 7 \text { women } \\
\text { post-partum who agreed to the research. Women were } \\
\text { observed during childbirth and their behaviour and } \\
\text { cognitive function were assessed. Each interview was } \\
\text { overwritten and analyzed using the Van Manena method. } \\
\text { Seven women took part in the study in the postpartum } \\
\text { period. The women gave birth spontaneously, vaginally. } \\
\text { Of the total number of women, three were giving birth } \\
\text { for the first time, and four for the the second time. The } \\
\text { women were aged 28-32. }\end{array}$ & $\begin{array}{l}\text { This study used an interpretative } \\
\text { phenomenological approach (hermeneutic } \\
\text { phenomenology) to describe the } \\
\text { phenomenon of pain at work in Indonesia } \\
\text { from a mother's point of view. The results } \\
\text { revealed six interrelated topics: negative } \\
\text { experience with workplace pain; previous } \\
\text { knowledge to relieve pain; anxiety, but } \\
\text { the pain is to be experienced; the desire } \\
\text { to manage pain in labour; the desire to be } \\
\text { accompanied; and awareness of the mother's } \\
\text { needs. The findings showed that women } \\
\text { can handle pain at work due to a lack of } \\
\text { information about the birth process and the } \\
\text { belief that pain should be expected. }\end{array}$ \\
\hline $\begin{array}{l}\text { Karlsdottir et al. } \\
\text { (2014); } \\
\text { Finland }\end{array}$ & $\begin{array}{l}\text { Evaluate the } \\
\text { experience of women } \\
\text { with birth pain and } \\
\text { management of pain } \\
\text { in natural childbirth. }\end{array}$ & $\begin{array}{l}\text { Qualitative study - Data collection using the Vancouver } \\
\text { method. For women after birth, a semi-structured } \\
\text { interview. The conversation was conducted by only one } \\
\text { person, eliminating the risk of subjectivity. The research } \\
\text { comprised } 14 \text { women after spontaneous delivery. Seven } \\
\text { women were giving birth for the first time, } 7 \text { women had } \\
\text { already had a previous experience. Women were aged } \\
20-40 \text { years. Women's social status: three women were } \\
\text { married, nine women were single. }\end{array}$ & $\begin{array}{l}\text { Women described the importance of } \\
\text { complex management of birth pain, which } \\
\text { included the preparation of women for } \\
\text { labour and birth pain management, so that } \\
\text { women were prepared for various coping } \\
\text { strategies to alleviate labour pain. Finally, } \\
\text { assessments of birth pain during delivery, } \\
\text { midwifery assistance from birth pain, but } \\
\text { also communication, empathy, support for } \\
\text { better psychic birth, and overall handling of } \\
\text { this stressful situation. } \\
\text { In } 98 \% \text { midwife was an important } \\
\text { milestone in managing birth pain. Women } \\
\text { also described how important it was to have } \\
\text { a partner or a person who was close to them } \\
\text { with whom they had mutual understanding } \\
\text { to support their pain during labour. }\end{array}$ \\
\hline $\begin{array}{l}\text { Whitburn et al. } \\
\text { (2014); } \\
\text { Australia }\end{array}$ & $\begin{array}{l}\text { The aim of the work } \\
\text { was to evaluate the } \\
\text { experience of women } \\
\text { with labour pain, and } \\
\text { whether the psyche of } \\
\text { women participates } \\
\text { in experiencing pain. } \\
\text { A partial objective } \\
\text { was to evaluate the } \\
\text { factors that positively } \\
\text { or negatively affect } \\
\text { the psyche of a } \\
\text { woman during the } \\
\text { birth process. }\end{array}$ & $\begin{array}{l}\text { A qualitative study was carried out using phenomenology } \\
\text { as a theoretical framework. Data was gathered through } \\
\text { telephone conversations, which were then rewritten. } \\
\text { The results were analysed using thematic analysis of the } \\
\text { transcript. A total of } 19 \text { women participated in the study. } \\
10 \text { women were nulliparous, nine were multiparous. } \\
\text { Nine women were born in the hospital under the guidance } \\
\text { of an obstetrician, another } 10 \text { were born in the birth } \\
\text { centre with the help of an experienced midwife. } 14 \\
\text { women gave birth vaginally spontaneously, one by vaginal } \\
\text { extraction, four by surgery (caesarean section) because } \\
\text { there were umbilical complications. Two women had high } \\
\text { school education, } 2 \text { women had a university education, } \\
\text { and } 15 \text { women with postgraduate degrees. }\end{array}$ & $\begin{array}{l}\text { The results indicate that the state of the } \\
\text { female brain during the work process can } \\
\text { create a phase for cognitive and evaluation } \\
\text { processes. Based on this, thought processes } \\
\text { were catastrophic pain, low self-confidence } \\
\text { to manage delivery, and then a negative } \\
\text { assessment of women's pain. Women } \\
\text { considered that the birth of the birth pain } \\
\text { itself was influenced by their self-confidence, } \\
\text { which was based on the approach of a doctor } \\
\text { or midwife, on communication and on the } \\
\text { overall influence of the environment, all } \\
\text { of which falls within the cognitive group } \\
\text { of the psyche, which results in the pain } \\
\text { perception process itself. This implies that } \\
\text { it is important to focus on the birth itself, } \\
\text { which was reported by all } 19 \text { women. }\end{array}$ \\
\hline
\end{tabular}

\section{Midwife care using coping strategies}

The work highlights the positive approach of midwives who are part of the delivery processes. They are companions to the women, being available, assisting, and followed. It is important that a midwife gives a woman the chance to understand the nature of a birth, and to be responsible, which helps to establish a trustworthy relationship with both the midwife and herself. It is also important to have a close relative nearby during the birth (Escott et al., 2004; Leap et al., 2010; Lundgren and Dahlberg, 2002). Women reported that when a midwife offered, them help from birth pain, most used coping techniques such as breathing, relief, hydrotherapy, and more.

Parents rated positively the care of the midwife and the choice of coping techniques they had chosen in order to make the parents be content with their own birth and the manage- ment of labour pain. Women in most cases attended special pre-birth consulting meetings and were informed about coping strategies. The results show the importance of focusing on the problems and the fear of birth pain before birth, inform women about coping strategies in prenatal preparation and in cooperation with midwives, and then ensure adequate coping strategies based on individual needs during childbirth (Karlsdottir et al., 2014; Slade et al., 2000). But there is an emphasis on midwives knowing coping and communication strategies (Escott et al., 2004). The data suggests that midwives have rather poor awareness of coping strategies (Beige et al., 2010). Leap et al. (2010) and Karlsdottir et al. (2014), and these studies indicate the positive influence of midwife care in the care of a woman. 
The results confirmed that through the continuous, comprehensive care of a woman during pregnancy and during delivery by one midwife, women are better able to manage not only the pregnancy but also the birth, birth pain and enjoyed pharmacological methods of pain relief significantly less compared to non-pharmacological methods. Women rated positively birth control, labour pain, and were more satisfied with the care of the midwife who provided them with individual continuous care. Women reported that there was greater trust between them and midwives, which improved their overall relationship. These experiences have increased women's ability to overcome fear and self-doubt about how they cope with pain, and lead to a sense of pride, enthusiasm and empowerment in postnatal life. Women appeared to be encouraged more during delivery, and there was more collaboration with the midwife to use various non-pharmacological methods to manage labour pain, such as positioning, breathing exercises, hydrotherapy and others (Escott et al., 2004; Gibson, 2014; Karlsdottir et al., 2014; Leap et al., 2010; Lundgren and Dahlberg, 2002; Rachmawati, 2012; Whitburn et al., 2014).

\section{Model of care provided by midwives for women with labour pain}

There are two different opinions in the world about providing care to pregnant and nascent women with birth defects. The first model is associated with the provision of care by physicians, using pharmacological methods to suppress birth pain.

The philosophy of this model is the medical belief that birth pain is a pathological injury to the body and must be eliminated. Women should be offered the option to remove this pain. The second model focuses on the use of non-pharmacological methods to help women work with birth pain, i.e., midwife care using coping strategies. This model evaluates midwives as more effective as it better helps women psychologically to reduce stress during the pregnancy, reduces the fear of giving birth (and later during childbirth), improves women's self-esteem, offers better adaptation to childbirth and labour pain, uses coping strategies, reduces the use of pharmacological techniques to counteract birth pain and reduces various complications during childbirth (Roberts et al., 2010).

Gibson (2014) states in her study that midwife care and the familiarization of women with coping strategies (and their choice based on women's individual preferences and co-operation) lead to a better management of pregnancy and birth process.

The women who gave birth with the aid of an obstetrician spoke of a more painful birth; they had a negative experience, they were disappointed that they had been offered the choice of only pharmacological methods of help from labour pain, and more often had complications at the end of childbirth.

Nowadays, many women face the problem that non-pharmacological pain relief methods are seldom used in medically managed childbirth, which, of course, leads to further problems, such as disruption of parturition delivery and others. The trend shows a higher demand for alternative pain relief techniques, as confirmed by Karlsdottir et al. (2014), which confirms that midwifery should be at the forefront of providing parental care, since it helps to better estimate individual prerequisites while providing parental care, and it better assesses the individual needs of a woman, depending on the birth process. Midwives play an important role in working with women in preparing for pregnancy, in giving birth, and ultimately in managing the birth and birth pain using just the psychotherapeutic coping strategies. The positive effect of the continuous non-pharmacological model of midwife care using coping strategies is shown by Escott et al. (2004), Lundgren and Dahlberg. (2002) and Roberts et al. (2010). Their results should improve the quality of care provided in modern obstetrics and the satisfaction of women with the pregnancy itself.

\section{Discussion}

Birth pain is a special category of pain in which the physiological significance interferes with pathophysiological mechanisms (Mander, 2014, p. 48). Birth pain is a specific phenomenon in midwifery, which is influenced by a number of factors including women's personality, cultural habits, traditions, but also the influence of personality traits, external physical phenomena, the physical condition of a woman and many others. One of the most influential factors is the effect of the environment, which includes the environment where a child is born, but also the social environment, the influence of health care providers, and close relatives. Birth pain management, individual experiencing and perceiving of birth pain can be seen as the most important among all other activities performed by the medical staff, in particular, a midwife and her approach to childbirth and a woman, communication, empathy, as confirmed by several domestic and international studies (Karlsdottir et al., 2014; Leap et al., 2010; Rachmawati, 2012; Whitburn et al., 2014). This literary study serves to highlight the importance of understanding complex birth pain, preparing for birth pain in the prenatal period, adaptation of coping strategies, and then providing adequate supportive help considering this phenomenon during natural birth depending on the individuality of the woman. Continuous care provided by a midwife during pregnancy is treated as very important as well as the care offered during a postpartum period. It helps turning a birth process into a natural event in the life of a woman while also promoting the newborn'svitality (Karlsdottir et al., 2014; Leap et al. 2010; Rachmawati, 2012; Whitburn et al., 2014).

Mander (2014) suggests that organizational changes in the context of maternity care are necessary to advocate this continuity and meaningful interactions between health workers and women as recommended by this survey on birth pain, which highlights the methodological issues that have been observed in previous reviews of qualitative literature (Escott et al.; 2004; Lundgren and Dahlberg, 2002). Literary research shows the contribution of continuity of care in relation to the ability to manage birth pain and the natural process of childbirth regardless of ethnicity, culture, and socio-economic status. All selected studies indicate that midwife's support and care using non-pharmacological coping strategies that women received during labour, including the relationship, were the most important influences in the perception of birth and the management of labour-induced pain without pharmaceuticals which contradicts the bio-medical model of care and resulted in medication administration, which points to the need to treat pain through pharmacological methods. Better birth control and labour pain lead to better cooperation between a parent and a midwife, resulting in natural birth and risk and complication elimination during childbirth and postpartum, and the reduction of negative experiences with the birth itself (Klomp et al., 2013; Kuliukas et al., 2016; Lowe, 2000).

This could be reflected in the arguments that the acceptance of pain further reduces the need for parental care to be associated with complications and thus reduce the length of hospitalization in the postpartum period. In addition, research has highlighted the need for knowledge of birth pain, physiology, management, knowledge of various methods, both phar- 
macological and non-pharmacological, to help with birth pain and the need to inform women before birth (Leap et al., 2010).

The main benefit of the literary review is shifting of social standards in the provision of care during pregnancy, childbirth and postpartum to women at a time when there is a conflict between companies and health services. Nowadays the influence of the media on future mothers is increasing. Women are increasingly trying to take an active part in the process of childbirth and make decisions about it. However, we consider that understanding childbirth as a natural process and a tremendously important event in a woman's life connected with her identification with a new role is very critical in midwifery. To meet the needs of a woman there should be a midwife who will provide a continuous care from the beginning of pregnancy until the postpartum period

\section{Conclusions}

A qualitative literary review examining pain at childbirth reflects the current biomedical model of childbirth, which is often manifested in the 21st Century Antepartal Care System. Although there is currently no qualitative research investigating the experience of labour pain during delivery, traceable research is available, which mainly assesses the use of pharmacological methods and coping strategies to help with birth pain.

There are not so many studies dealing with coping strategies used in care programmes designed for a pregnant woman with childbearing pain, so it is important to look at birth pain from a multidimensional standpoint; the physiology of labour pain, factors that influence the development and coping with birth pain, the ability to manage birth pain, understanding of how women interpret their ability to manage pain regardless of individual or contextual differences that are highlighted in the findings, and taking into consideration educational cooperation between women and midwives during the pre-birth period.

All this should lead to a change in the understanding of the care provided during pregnancy and during childbirth, but also in the postpartum period and the creation of a new model of care provided during delivery in midwifery. For this reason, we strive to focus on birth pain in a comprehensive way, to know the preterm period of women, to evaluate the pain and its management, and then to provide women with various pain relief options. Finally, women should be offered sup- port, empathy, environmental adaptation, and midwives with non-pharmacological coping strategies. In the most complicated cases, pharmacological methods can be applied according to the actual condition of a woman. Unfortunately, this is also a big issue today, which sometimes negatively affects the natural process of childbirth due to delaying labour pain occurrence in uterine activities. All this leads to induced, pharmacological births, surgically terminated labours, increased risk of injuries in the second birth periods and others (Klomp et al., 2013; Kuliukas et al., 2016).

For this reason, we want to focus more on the use of various non-pharmacological methods: coping strategies such as effective breathing, positioning, aromatherapy, midwife's support, being under the care of only one midwife during childbirth, and others focused primarily on a woman's mental state and her basic needs, which leads to better management of birth pain by women and the reduction of stress hormones, which also contributes to increased sensitivity to birth pain. Supporting and passing on information and helping a woman during childbirth reduces anxiety that leads to the motivation to overcome an obstacle, which in our case is the birth pain.

For a woman, a midwife is a person who offers accessibility, reliability, emotional and physical support. Care in midwifery is constantly evolving and is a challenge for both midwifery nursing theorists and midwifery in practice. The described findings could help to reflect the nature of care in midwifery, as a basic phenomenon in nursing, and show possible improvement of provided care for women; the creation of a new nursing model in the care provided by midwives, the use of a memory sheet in midwifery focused on the basic interventions provided by a midwife to a woman during childbirth and their evaluation. The results could also be used in the area of nursing care, care of women, communication with women, and in the development of midwifery care in prenatal, perinatal and postnatal care.

\section{Limitations of the study}

Only publications in English that were available in electronic bibliographic databases were included in the literary research.

\section{Ethical aspects and conflict of interest}

The authors declare that the research in the literary review has no conflict of interest and that all ethical aspects have been observed.

\section{Copingové strategie $\mathrm{v}$ péči porodní asistentky o rodící ženu}

\section{Souhrn}

Cíl: Byla provedena literární review, analýza literárních zdrojů zabývající se péčí porodní asistentky s využitím copingových strategií u rodící ženy s porodní bolestí.

Design: Přehledová studie.

Metodika: Kvalitativní studie byly vyhledány systematickou rešerší v elektronických databázích Pubmed, Web of Science, Journal of Midwifery, CINAHL, Cochrane, podle stanovených kritérií a definovaných klíčových slov: coping, porod, porodní bolest, strategie, za období září 2017 - červen 2018. Studie byly z období let 2000-2014. Získané studie byly tř́iděny podle doporučení Prisma. Výsledky: Byly porovnány studie z Velké Británie, Irska, Ameriky a Austrálie. Studie poukázaly na pozitivní vliv porodní asistentky, jež využívá copingové strategie, zapojuje ženu do porodního procesu a nechá ji rozhodovat o jeho průběhu. Tento vztah vede k lepšímu prožívání a vnímání porodních bolestí ženami jako k něčemu pozitivnímu a potřebnému při porodu; je to spolupráce s porodní asistentkou a zvládnutí samotného porodu bez rizik a komplikací.

Závěr: Myšlenkou moderního ošetřovatelství v porodní asistenci má být komplexní, kontinuální péče jedné porodní asistentky o ženu v průběhu těhotenství, porodu a poporodního období, ke které má žena vztah a důvěru. To vede k eliminaci narušení př́irozeného procesu těhotenství a porodu, snížení možných rizik a komplikací a posléze k pozitivnímu prožití těhotenství, porodu a navázání kontaktu mezi ženou a novorozencem.

Klíčová slova: coping, péče; porod; porodní bolest; strategie 


\section{References}

1. Beige N, Broumandfar K, Bahadoran P, Abedi H (2010). Women's experience of pain during childbirth. Iran J Nurs Midwifery Res 15(2): 77-82.

2. Escott D, Spiby H, Slade P, Fraser RB (2004). The range of coping strategies women use to manage pain and anxiety prior to and during first experience of labour. Midwifery 20(2): 144-156. DOI: $10.1016 /$ j.midw.2003.11.001.

3. Gibson E (2014). Women's expectation and experiences with labour pain in medical and midwifery models of birth in the United States. Women Birth 27(3): 185-189. DOI: 10.1016/j. wombi.2014.05.002.

4. Karlsdottir SI, Halldorsdottir S, Lundgren I (2014). The third paradigm in labour pain preparation and management: the childearing woman's paradigm. Scand J Caring Sci 28(2): 315-327. DOI: 10.1111/scs.12061.

5. Klomp T, de Jonge A, Hutton EK, Lagro-Janssen AL (2013). Dutch women in midwife-led care at the onset of labour: which pain relief do they prefer and what do they use? BMC Pregnancy Childbirth 13: 230. DOI: 10.1186/1471-2393-13-230.

6. Kuliukas L, Duggan R, Lewis L, Hauck Y (2016). Women's experience of intrapartum transfer from a Western Australian birth centre co-located to a tertiary maternity hospital. BMC Pregnancy Childbirth 16(1): 33. DOI: 10.1186/s12884-0160817-z.

7. Leap N, Sandall J, Buckland S, Huber U (2010). Journey to confidence: women's experiences of pain in labour and relation continuity of care. J Midwifery Womens Health 55(3): 234-242. DOI: 10.1016/j.jmwh.2010.02.001.

8. Lowe N (2000). Self-efficacy for labor and childbirth fears in nulliparous pregnant women. J Psychosom Obstet Gynecol 21(4): 219-224. DOI: 10.3109/01674820009085591.

9. Lundgren I, Dahlberg K (2002). Midwives' experience of the encounter with women and their pain during childbirth. Midwifery 18(2): 155-164. DOI: 10.1054/midw.2002.0302.

10. Mander R (2014). Těhotenství, porod a bolest. Praha: Triton.

11. Rachmawati IN (2012). Maternal reflection on labour pain management and influencing factors. BJM 20(4): 263-270. DOI: 10.12968/bjom.2012.20.4.263.

12. Ratislavová K (2008). Aplikovaná psychologie porodnictví. Praha: Reklamní atelier Area.

13. Raudenská K, Santlerová K, Marusičová P, Hanulíková $\mathrm{P}$, Amlerová J, Javůroková A (2014). Strach související s porodní bolestí. Bolest 17(3): 105-110.

14. Roberts L, Gulliver B, Fisher J, Cloyes KG (2010). The coping with labor algorithm: an alternate pain assessment tool for the laboring woman. J Midwifery Women's Health 55(2): 107-116. DOI: 10.1016/j.jmwh.2009.11.002.

15. Slade P, Escott D, Spiby H, Henderson B, Fraser RB (2000). Antenatal predictors and use of coping strategies in labour. Psychol Health 15(4): 555-569. DOI: 10.1080/08870440008402013.

16. Whitburn LY, Jones LE, Davey MA, Small R (2014) Women's experiences of labour pain and the role of the mind: an exploratory study. Midwifery 30(9): 1029-1035. DOI: 10.1016/j.midw.2014.04.005. 